\title{
PANORAMA JURANG TOLEH, JATIGUWI, SUMBERPUCUNG, KABUPATEN MALANG, JAWA TIMUR
}

\author{
Sri Widayati' ${ }^{1)}$, Pungky Eka Setyawan'), Elta Sonalitha ${ }^{3)}$ \\ 1) Fakultas Ilmu Sosial \& Ilmu Politik, Universitas Merdeka Malang \\ ${ }^{2)}$ Fakultas Teknik, Universitas Merdeka Malang \\ ${ }^{3)}$ Fakultas Teknologi Informasi Universitas Merdeka Malang \\ Email: sri.widayati@unmer.ac.id
}

\begin{abstract}
Abstrak
Potensi terbesar dari desa Jatiguwi adalah Ikan Air Tawar yang setiap hari panen ikan. Hasil panen langsung dijual di pasar atau didistribusikan ke beberapa tempat penjualan ikan air tawar di wilayah Kota dan Kabupaten Malang. Ikan langsung dibeli oleh para pelanggan yang datang ke tempat-tempat penjualan ikan tersebut, sedangkan Desa Jatiguwi sendiri sebagai penghasil ikan air tawar Karamba terbesar di wilayah Kabupaten Malang justru tidak memiliki tempat penjualan ikan air tawar secara khusus. Hasil panen ini langsung dibeli oleh para pelanggan yang datang ke tempat-tempat penjualan ikan tersebut. Namun, Ikan-ikan air tawar ini dijual langsung tanpa diolah terlebih dahulu, sehingga harga nya relatif murah dan keuntungan yang diterima nelayan sangatlah sedikit. Dibutuhkan suatu metode yang dapat mengangkat nilai jual dari hasil panen ikan air tawar tersebut.

Potensi lain dari desa ini adalah keindahan sunset dan keramba-keramba dengan pemandangan yang indah, pemandangan ini jika dimanfaatkan dengan baik akan menjadi daya Tarik wisata yang unik. Desa masih kesulitan untuk maengembangkan potensi ini menjadi obyek wisata untuk meningkatkan kesejahteraan masyarakat. Mitra ingin mewujudkan pengembangan lokasi menjadi wisata edukasi yang menarik perhatian wisatawan dan dapat meningkatkan nilai jual tempat wisata tersebut. Mitra membutuhkan pendampingan dan pelatihan-pelatihan dalam mewujudkan desa wisata yang layak.

Di desa jatiguwi terdapat banyak lahan kosong milik pemerintah desa yang layak dijadikan area-area edukasi atau area wisata kuliner hasil panen air tawar. Dari beberapa permasalahan mitra yang ada, Solusi yang ditawarkan adalah (1) Pendampingan pembenahan area wisata dari bangunan-bangunan yang kurang layak, merapikan area, mengorganisasi sampah, dan penyediaan sarana dan prasana yang dibutuhkan oleh sebuah desa wisata pelatihan (2) Pelatihan tentang excellent service yaitu pembinaan, pengajaran dan pembimbingan masyarakat bagaimana memberikan pelayanan yang ramah dan pintar kepada wisatawan sehingga wisatawan sehingga dapat merasa nyaman dan senang telah berkunjung di desa Jatiguwi (3) Pelatihan untuk sumber daya manusia tentang tata kelola atau manajemen eco Wisata (4) Publikasi eco wisata Jatigui secara online yang bertujuan memasarkan tempat wisata agar lebih dikenal wisatawan, baik dalam negeri maupun luar negeri
\end{abstract}

Kata kunci: Budidaya Ikan, Ikan Air Tawar, Jatiguwi, Karamba, Wisata Air

\section{PENDAHULUAN}

Desa Jatiguwi Kabupaten Malang adalah desa penghasil ikan air tawar terbesar di Malang Raya. Desa ini terletak di dalam wilayah Kecamatan Sumberpucung terletak sekitar $\pm 30 \mathrm{~km}$ di sebelah selatan Kabupaten Malang.

Pemandangan di desa ini berpotensi wisata disamping tempat berbelanja ikan bagi pengunjung desa. Pemanfaatan desa sebagai tempat wisata sebenarnya sudah diterapkan di desa ini, namun pemerintah desa mengeluhkan tidak adanya kemajuan dari tempat wisata ini, dari sisi sosial ekonomi penduduk setempat. Hal ini dikarenakan ketidakterampilnya masyarakat mengelola sarana, prasarana dan sumber daya manusia desa tentang pengelolaan desa sebagai tempat wisata.
Potensi terbesar dari desa ini adalah Ikan Air Tawar yang setiap hari panen. Hasil panen langsung dijual di pasar atau didistribusikan ke beberapa tempat penjualan ikan air tawar di wilayah Kota dan Kabupaten Malang. Ikan langsung dibeli oleh para pelanggan yang datang ke tempat-tempat penjualan ikan tersebut, sedangkan Desa Jatiguwi sendiri sebagai penghasil ikan air tawar Karamba terbesar di wilayah Kabupaten Malang justru tidak memiliki tempat penjualan ikan air tawar secara khusus. Ikanikan air tawar ini dijual langsung tanpa diolah terlebih dahulu, sehingga harga nya relative murah dan keuntungan yang diterima nelayan sangatlah sedikit. Dibutuhkan suatu metode yang dapat mengangkat nilai jual dari hasil panen ikan air tawar tersebut.

Potensi lain dari desa ini adalah keindahan sunset dan keramba-keramba dengan pemandangan 
yang indah, pemandangan ini jika dimanfaatkan dengan baik akan menjadi daya Tarik wisata yang unik. Desa masih kesulitan untuk maengembangkan potensi ini menjadi obyek wisata untuk meningkatkan kesejahteraan masyarakat.

Mitra ingin mewujudkan pengembangan lokasi menjadi wisata edukasi yang menarik perhatian wisatawan dan dapat meningkatkan nilai jual tempat wisata tersebut. Mitra membutuhkan pendampingan dan pelatihan-pelatihan dalam mewujudkan desa wisata yang layak.

Di desa jatiguwi terdapat banyak lahan kosong milik pemerintah desa yang layak dijadikan area-area edukasi atau area wisata kuliner hasil panen air tawar. Dari beberapa permasalahan mitra yang ada, Solusi yang ditawarkan antara lain :

(1) Pendampingan pembenahan area wisata dari bangunan-bangunan yang kurang layak, merapikan area, mengorganisasi sampah, dan penyediaan sarana dan prasana yang dibutuhkan oleh sebuah desa wisata pelatihan

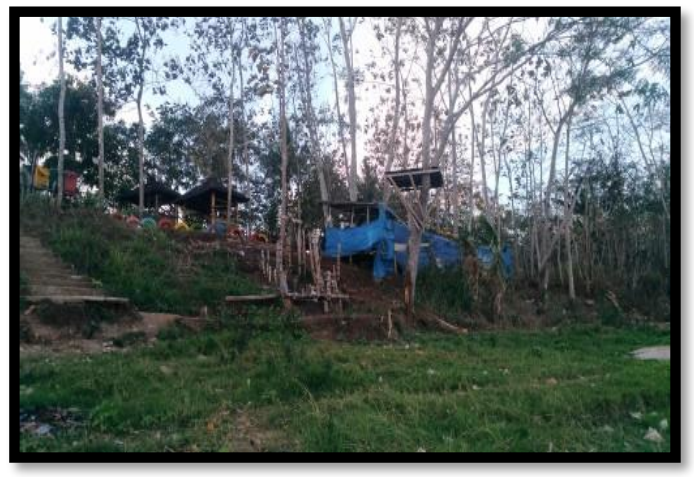

Gambar 1. Kendala pemandangan stan kuliner yang terlihat kumuh.

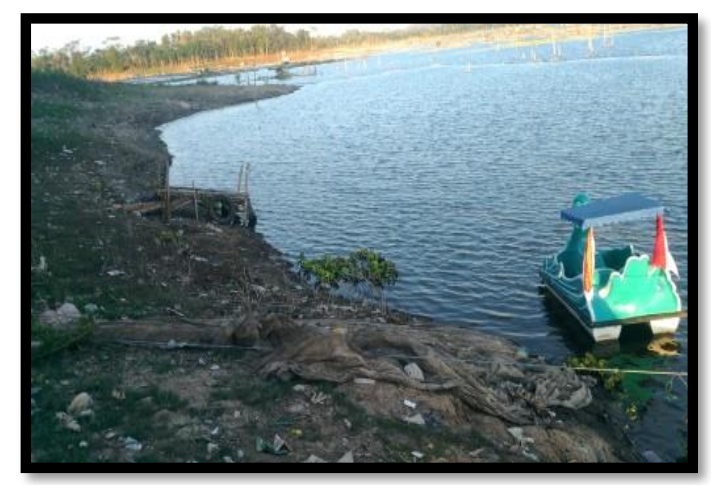

Gambar 2. Kendala Sampah kiriman dari danau yang belum mendapatkan solusi.

(2) Pelatihan tentang excellent service yaitu pembinaan, pengajaran dan pembimbingan masyarakat bagaimana memberikan pelayanan yang ramah dan pintar kepada wisatawan sehingga wisatawan sehingga dapat merasa nyaman dan senang telah berkunjung di desa Jatiguwi

(3) Ide menentukan Ikon Wisata Kuliner untuk Panorama Jurang Toleh dan Pelatihan pengolahan Ikan Mujair.

Keindahan Wisata Jurang Toleh di Desa Jatiguwi, Sumberpucung Kabupaten Malang merupakan wisata danau dan taman yang unik yang bisa menjadi destinasi wisata alternatif terbaru bagi traveller, lokasinya berada di Bonklopo, Desa Jatiguwi, Kecamatan Sumberpucung , Kabupaten Malang, Jawa Timur. Wisata Panorama Jurang Toleh menawarkan pemandangan danau dan taman asri sebagai tempat berteduh / bersantai sambil menikmati keindahan panorama danau.

\section{Panorama Jurang Toleh}

Wisata Panorama Jurang Toleh Sebelum menjadi salah satu alternatif tempat wisata di kota Malang, sudah menjadi tujuan favorit para mancing mania di Kota dan Kabupaten Malang. Atas inisiatif karang taruna Desa Jatiguwi dan Warga sekitar Danau tersebut disulap menjadi tempat tujuan wisata di Kabupaten Malang. Ide pembuatan inovasi desa "Panorama Jurang Toleh" berawal dari kesadaran masyarakat tentang potensi alam yang ada.

\section{METODE KEGIATAN}

Dari beberapa permasalahan mitra yang ada, Solusi yang ditawarkan antara lain :

(1) A. Pendampingan pembenahan area wisata dari bangunan-bangunan yang kurang layak.

$\mathrm{Di}$ area wisata terdapat beberapa stan makanan yang dinilai kurang rapi dan sekedarnya. Penataan stan ini menggunakan terpal-terpal yang tidak rapi sehingga merusak pemandangan keindahan alam. Selain itu para pedagang yang mengisi stand tidak terorganisir secara baik sehingga rentan menimbulkan perpecahan antar pedagang dan pengelola tempat wisata.

B. Menggali potensi pengolahan ikan air tawar sebagai kuliner khas Jatiguwi.

Makanan-makanan yang saat ini dijual di stand makanan ini juga bukan merupakan pengolahan ikan, hal ini sangat disayangkan, mengingat produk unggulan dari wilayah Jatiguwi adalah Ikan Air Tawar. makanan yang disajikan saat ini hanya makananmakanan ringan, snack, makanan dan minuman instant, bakso dan mie ayam.padahal salah satu view yang disajikan 
di lokasi ini adalah hamparan karamba ikan air tawar yang terbentang di tengah danau dan menghasilkan ikan air tawar yang melimpah setiap hari.

Kuliner adalah salah satu daya tarik wisata yang luar biasa jika digali dan dikelola dengan baik.

C. Re-Desain dan Merapikan Area wisata

Pembenahan lingkungan dan redesain area wisata ini akan dilakukan bersama karang taruna dan masyarakat sekitar area wisata. Tentu saja dukungan dari pemerintah desa sangat dibutuhkan untuk mobilisasi masyarakat.

penataan akan mereferensi desa-desa wisata lainnya yang sudah bagus dan layak sebagai desa wisata, karena ada kecenderungan keberadaan taman wisata Panorama Jurang Toleh semakin hari bukan semakin bagus tetapi sebaliknya semakin tidak terawat dan terkesan berantakan.

Mengorganisasi sampah, dan penyediaan sarana dan prasana yang dibutuhkan oleh sebuah tempat wisata.

Solusi yang ditawarkan untuk membersihkan sampah-sampah adalah, dengan merancang sebuah penggulung jaring dan terpal secara otomatis yang digelar pada saat air pasang, dan diharapkan pada saat air surut, sampahsampah tersebut terkumpul dalam satu jaring, sehingga mudah untuk di buang atau dibakar.

D. Merapikan dan mengorganisasi sarana-dan prasarana umum.

E. Pentingnya penyediaan fasilitas umum yang layak seperti toilet dan tempat ibadah, sangat mempengaruhi kenyamanan pengunjung. Kebersihan dan kerapian merupakan faktor utama. Toilet di area ini tidak dipungut biaya, kelemahannya adalah, kurangnya biaya untuk merawat dan membersihkan toilet dan ketidaktersediaan air di toilet.

(2) Pelatihan tentang excellent service yaitu pembinaan, pengajaran dan pembimbingan masyarakat bagaimana memberikan pelayanan yang ramah dan pintar kepada wisatawan sehingga wisatawan dapat merasa nyaman dan senang telah berkunjung di desa Jatiguwi. Karena Kelompok Sadar Wisata Desa Jatiguwi yang selama ini diberikan mandat oleh pemerintah desa untuk mengelola kawasan ini terkesan ogahogahan dalam memberikan pelayanan kepada pengunjung.
Potensi ekonomi dan wisata di desa Jatiguwi cukup tinggi, sehingga ke depan dapat menjadi salah satu destinasi wisata handal di kabupaten Malang. Pelatihan Excellent Service bagi Pegiat Wisata setempat memberikan nilai tambah kepada masyarakat untuk menjadikan Wisata Jurang Toleh sebagai destinasi bukan hanya nasional tetapi sampai tingkat Internasional.

Panorama dan potensi wisata desa Jatiguwi cukup indah, dengan pelayanan yang baik dan pintar kepada wisatawan akan memberikan kesan positif dan memuaskan wisatawan sehingga mereka akan kembali dan menceritakan kesan positif mereka kepada orang lain. semakin banyaknya kesan baik yang diterima wisatawan dan bertambahnya pengunjung maka akan memberikan dampak ekonomi bagi warganya melalui berbagai usaha wisata.

Usai pelatihan diharapkan para pegiat wisata memberikan layanan prima kepada wisatawan, agar kunjungan wisata lebih menggeliat dan meningkat, hingga mampu meningkatkan kesejahteraan masyarakat setempat.

(3) Pelatihan untuk sumber daya manusia tentang tata kelola atau manajemen eco Wisata. Langkah-langkah strategis menggerakkan Sumber daya Manusia untuk mengembangkan potensi desa wisata, antara lain :

a. Identifikasi potensi desa melalui rembug bersama seluruh komponen desa dari semua kalangan. Potensi yang dapat menjadi komoditas bisa bermacam-macam dari segala aspek. Bisa keindahan alam, hasil bumi, kekayaan flora fauna/hayati, sosio kultural, masyarakat, tradisi atau hal-hal yang bersifat khas/unik yang tak dimiliki daerah lain. Pastikan potensi unggulan yang akan dijadikan komoditas utama

b. Identifikasi permasalahan yang bisa jadi penghambat bagi pengembangan potensi wisata desa, mulai dari yang bersifat fisik, non fisik atau sosial, internal dan eksternal. Atau bisa saja permasalahan tersebut jika diolah dengan cara tertentu justru permasalahan itu bisa menjadi potensi

c. Perlunya komitmen yang kuat dari seluruh komponen desa untuk menyamakan pendapat, persepsi dan mengangkat potensi desa guna dijadikan desa wisata. Komitmen ini yang menjadi dukungan terkuat bagi 
terwujudnya dan keberlangsungan desa wisata

d. Identifikasi dampak baik dampak positif maupun negatif dari sebuah kegiatan wisata sesuai kekhasan desa. Masing-masing desa memiliki karakteristik sendiri akan menghasilkan dampak yang juga berbeda satu sama lain terutama perubahanperubahan sosial kultural

e. Komitmen yang kuat dari seluruh komponen desa untuk menggandeng Pemerintah Daerah dan jika perlu menggandeng pihak swasta. Tentunya dampak yang mungkin timbul akibat bekerjasama dengan pihak swasta juga harus dipikirkan dan diidentifikasi. Termasuk permasalahan penganggaran guna pembangunan desa wisata dengan menggunakan seluruh sumber daya ekonomi yang ada

f. Menyiapkan segala perangkat-perangkat aturan/regulasi norma yang lebih bertujuan untuk mengawal pengembangan desa wisata dan mengawasi potensi-potensi penyimpangan yang mungkin saja bisa terjadi. Regulasi disiapkan agar berjalannya aktivitas wisata beserta dampaknya tetap berada dalam koridor regulasi sebagai payung hukumnya

g. Melakukan pelatihan-pelatihan bagi seluruh komponen desa, termasuk pemerintah desa tentang manajemen pariwisata, bagaimana mengelola tempat wisata, manajemen tamu/pengunjung, beserta inovasi-inovasi yang perlu dikembangkan mengingat sebagaimana sektor lainnya sektor pariwisata pun mengalami fluktuasi dan bisa mengalami "kejenuhan"

h. Gunakan segala media untuk memperkenalkan dan mempublikasikan potensi wisata di desa baik media konvensional maupun non konvensional, seperti media internet. Internet kini menjadi sarana publikasi yang sangat efektif yang bisa menjangkau seluruh belahan bumi. Tempat wisata yang lokasinya terpencil pun bisa diketahui oleh orang di belahan dunia lain pun berkat teknologi internet

i. Belajar pada kesuksesan desa wisata lain atau studi banding. Kita bisa belajar banyak pada keberhasilan desa wisata lain khususnya yang sejenis. Karena tipikal permasalahan dan tantangan masa depan yang bakal dihadapi kurang lebih sama. Hanya dengan manajemen profesional dan inovatif saja desa wisata akan eksis dan kompetitif dan dapat melalui ujian yang bersifat internal, eksternal maupun regional internasional

(4) Publikasi Wisata Jatiguwi secara online yang bertujuan memasarkan tempat wisata agar lebih dikenal wisatawan, baik dalam negeri maupun luar negeri.

Pembuatan Web Commerse dan Profil desa yang menarik merupakan alat utama dalam proses marketing desa wisata.

Pembuatan dan Pelatihan kepada administrator mitra karang taruna mengenai pemanfaatan teknologi informasi sebagai alat untuk pemasaran secara online. Pembuatan akun resmi media sosial facebook, Instagram, Line dan sosial media lainnya tentang desa wisata Jatiguwi akan menambah luasan jaringan promosi wisata.

Maintenance konten dari web publikasi dan sosial media merupakan hal penting yang terusmenerus harus dilakukan. semakin up-to-date informasi semakin besar pula kepercayaan pembaca terhadap eksistensi tempat wisata.

\section{HASIL DAN PEMBAHASAN}

Dari beberapa permasalahan mitra yang ada,

Solusi yang ditawarkan antara lain:

(1) Pendampingan pembenahan area wisata dari bangunan-bangunan yang kurang layak, Di area wisata terdapat beberapa stan makanan yang dinilai kurang rapi dan sekedarnya. Penataan stan yang menggunakan terpal-terpal yang tidak rapi sehingga merusak pemandangan keindahan alam sudah dibongkar.

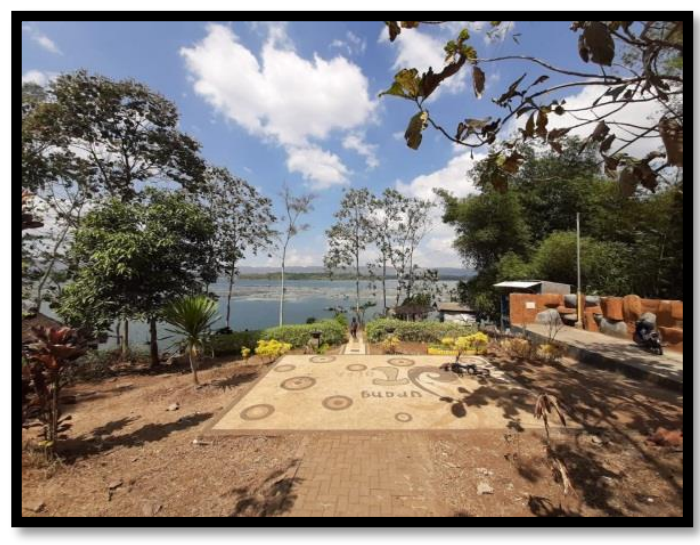

Gambar 3. Pembenahan Area Wisata 
(2) Menggali potensi pengolahan ikan air tawar sebagai kuliner khas Jatiguwi. Makananmakanan yang saat ini dijual di area ini bukan merupakan pengolahan ikan, Hal ini sangat disayangkan, mengingat produk unggulan dari wilayah Jatiguwi adalah Ikan Air Tawar. makanan yang adisajikan saat ini hanya makanan-makanan ringan, snack, makanan dan minuman instant, bakso dan mie ayam. Kuliner adalah salah satu daya tarik wisata yang luar biasa jika digali dengan baik.

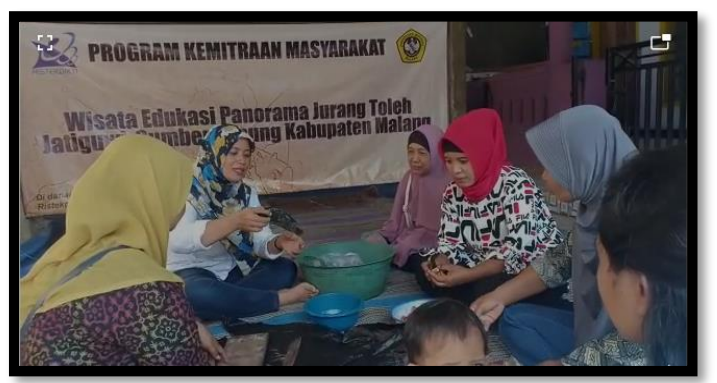

Gambar 2. Pelatihan Kuliner Mujair

(3) Selain kuliner Ikan Mujair, Pengabdi juga memberikan pelatihan UMKM dan pengolahan daun Kelor menjadi bahan seduhan instant sampai pengemasan
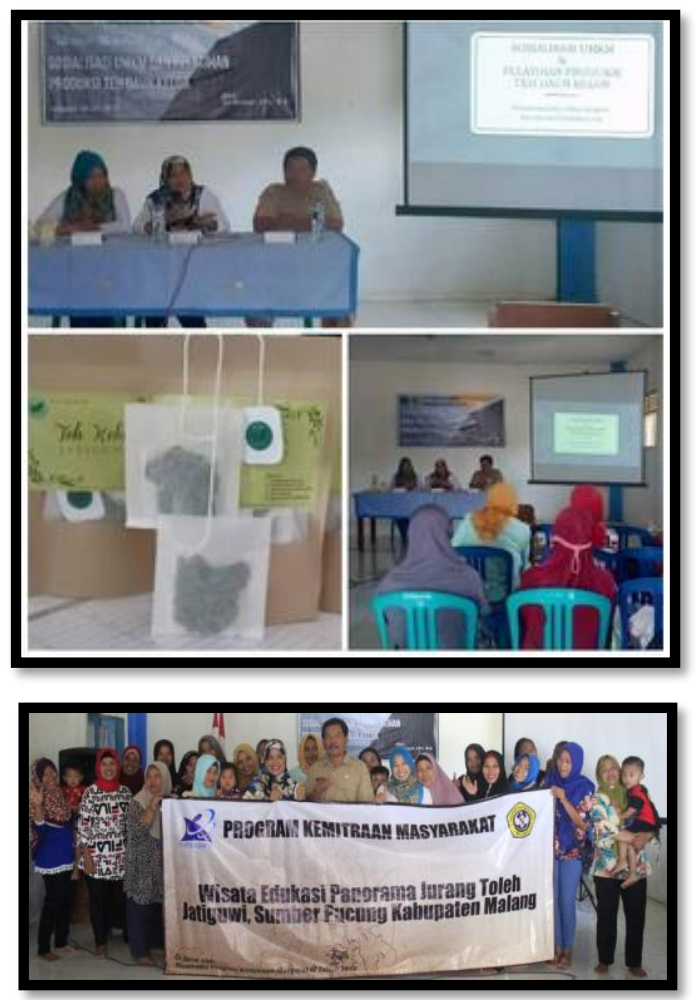

Gambar 3. Pelatihan Pengolahan Teh Kelor sampai Pengemasan

(4) Pelatihan tentang excellent service yaitu pembinaan, pengajaran dan pembimbingan masyarakat bagaimana memberikan pelayanan yang ramah dan pintar kepada wisatawan sehingga wisatawan sehingga dapat merasa nyaman dan senang telah berkunjung di desa Jatiguwi.

Potensi ekonomi dan wisata di desa Jatiguwi cukup tinggi, sehingga ke depan dapat menjadi salah satu destinasi wisata handal di kabupaten Malang. Pelatihan Excellent Service bagi Pegiat Wisata setempat memberikan nilai tambah kepada masyarakat untuk menjadikan Wisata Jurang Toleh sebagai destinasi bukan hanya nasional tetapi sampai tingkat Internasional.

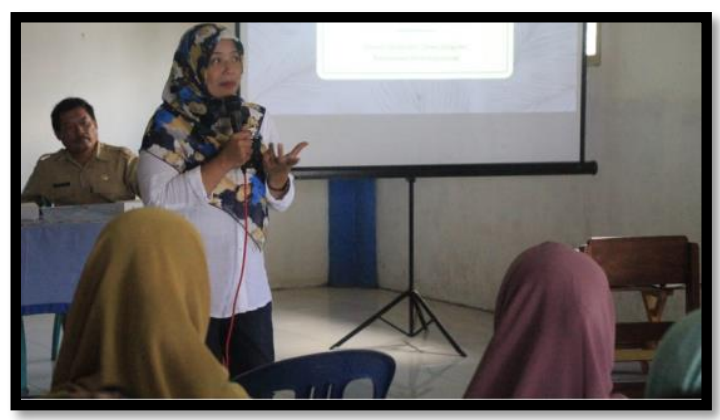

Gambar 4. Pelatihan Komunikasi Efektif kepada Karang Taruna Desa Jatiguwi

Panorama dan potensi wisata desa Jatiguwi cukup indah, dengan pelayanan yang baik dan pintar kepada wisatawan akan memberikan kesan positif dan memuaskan wisatawan sehingga mereka akan kembali dan menceritakan kesan positif mereka kepada orang lain. semakin banyaknya kesan baik yang diterima wisatawan dan bertambahnya pengunjung maka akan memberikan dampak ekonomi bagi warganya melalui berbagai usaha wisata.

Usai pelatihan para pegiat wisata dapat memberikan layanan prima kepada wisatawan, agar kunjungan wisata lebih menggeliat dan meningkat, hingga mampu meningkatkan kesejahteraan masyarakat setempat.

\section{KESIMPULAN}

Dampak serta manfaat dari pelaksanaan kegiatan pengabdian ini antara lain pemberdayaan sumber daya Jatiguwi dalam rangka meningkatkan kualitas area wisata yang berpengaruh pada peningkatan pengunjung area wisata sehingga meningkatkan kesejahteraan warga di sekitar area wisata Jurang Toleh. 


\section{PENGHARGAAN}

Penulis menyampaikan ucapan terima kasih kepada Kemenristek Dikti untuk dukungan program Pengabdian Kepada Masyarakat (PKM) tahun 2019, di Jurang Toleh, Desa Jatiguwi, Kecamatan Sumbrpucung kabupaten Malang, serta kepada pihakpihak yang turut membantu kelancaran kegiatan tersebut.

\section{REFERENSI}

Huraerah, Abu. 2011. Pengorganisasian \& Pengembangan Masyarakat. Bandung: Humaniora

Beevers, R. (2000). Customer Service Excellence in the Public Sector,, UK, Nothern Housing Consortium.
Johnston, D., W \& Johnsono, F., P., (2000). Joining Together Group Theory and Group Skills, Boston : Allyn \& Bacon

Mathis, R., L., \& Jackson, J., H. (2006). Human Resource Management: Manajemen Sumber Daya Manusia, Jakarta: Salemba Empat.

Asmal, M. (2011). Pengaruh Pelatihan Komunikasi Interpersonal terhadap Kualitas Layanan di RSUD Sleman.Tesis (tidak diterbitkan). Program Magister Profesi Psikologi Fakultas Psikologi dan Ilmu Sosial Budaya Universitas Islam Indonesia, Yogyakarta. 